COBISS: 1.01

\title{
FORMATION OF THE CERKNIŠČICA AND THE FLOODING OF CERKNIŠKO POLJE
}

\author{
NASTANEK CERKNIŠČICE IN POPLAVLJENJE \\ CERKNIŠKEGA POLJA
}

FRANCE ŠUŠTERŠIČ ${ }^{1} \&$ SIMONA ŠUŠTERŠIČ ${ }^{2}$

${ }^{1}$ France Šušteršič, University of Ljubljana, Dept. of Geology, Aškerčeva 12, SI-1000 Ljubljana, Slovenia; e-mail: france.sustersic@ntfgeo.uni-lj.si

${ }^{2}$ Simona Šušteršič, Laze 22, SI-1370 Logatec, Slovenia; e-mail: simona_sustersic@hotmail.com

Prejeto / received: 17. 4. 2003 


\section{Abstract}

UDC: 551.44:556.166

France Šušteršič \& Simona Šušteršič: Formation of the Cerkniščica and the flooding of Cerkniško polje

Detailed study of the upper Cerkniščica's catchment and its sediments in Cerkniško polje revealed that the river turned this direction in the middle Würm, while in the more remote past, the input to Cerkniško polje (and to the caves) was completely karstic. Its alluvial fan cut the main vertical ponors, and deflected the main polje outflow westwards, indirectly into Planinsko polje. Consequently, recent hydrogeological conditions in Planinska jama are a direct consequence of development in Cerkniško polje.

Key words: karst of Slovenia, Cerkniško polje, polje, Notranjski kras, flooding of poljes.

\section{Izvleček}

UDK: 551.44:556.166

\section{France Šušteršič \& Simona Šušteršič: Nastanek Cerkniščice in poplavljenje Cerkniškega polja}

Podrobna raziskava gornjega porečja Cerkniščice in njenih sedimentov v Cerkniškem polju je pokazala, da se je rečica v kotanjo polja pretočila šele srednjem Würmu, medtem ko je bil dotok v Cerkniško polje (in ponorne jame) dotlej popolnoma kraški. Njen vršaj je odrezal severne ponore in preusmeril glavni dotok $\mathrm{s}$ polja proti zahodu, posredno na Planinsko polje. Zato so današnje hidrološke razmere v Planinski jami neposredna posledica dogajanj na Cerkniškem polju.

Ključne besede: kras Slovenije, Cerkniško polje, kraško polje, Notranjski kras, poplavljanje kraških polj. 


\section{INTRODUCTION}

In earlier papers concerning the Late Quaternary dynamics of Planinska jama (Šušteršič et al. 2002-a, 2002-b) we stated that, among other catastrophic events, inrush of the Rak into the Eastern Branch in Würm II changed the situation the most radically. New quantities of water reversed the preexisting flow direction in the Eastern Branch and joined the Pivka to form the Unica river, followed by redirection of the outflow into the Northern Branch. This paper sets out to discuss the wider circumstances of why at some specific moment general circumstances in the hydrological backgroundof the Eastern Branch changed so radically.

Today the Rak at the lower water level is true, integral, and not increased continuation of the Cerkniščica. (Gams, 1966, 15). Thus, it appears that the roots of the development of Planinska jama must be sought in Cerkniško polje ${ }^{2}$. Most of its tributaries are karstic; i.e. they emerge from karstic springs on the polje border, only the Cerkniščica River provides the only significant nonkarstic input less table than purely karstic springs.

\section{ACTIVE DRAINAGE OF CERKNIŠKO POLJE}

At present Cerkniško polje drains into vertical ponors and cave ponors. Vertical ponors are narrow and tight, evidently immature and unmodified openings in the rock beneath the alluvial cover. If the present, artificially constrained, Cerkniščica did not flow into the artificially modified Karlovice Cave, all of the lower waters would disappear into vertical ponors on the extreme southern margin of the alluvial cone lobe. Complex water tracing experiments revealed relatively rapid $\left(7.4 \mathrm{~cm} \mathrm{~s}^{-1}\right)$ underground flow between the Vodonos (vertical) ponor and the Ljubljanica springs (Fig.1), confirming that highly transmissive karst channels lie between (Gospodarič \& Habič, 1976). So, any significant obstacles must occur only at the beginning of the route, and this can be explained because the vertical ponors merely provide shortcuts to a partly reactivated Loško system (See Fig.1 and the following text!).

Newly developed sinks in the Cerkniščica alluvial cone indicate that fluvial sediment has buried a previously active ponor area. This is most clearly evident at the toe of the cone were recent sapping is so intense that local inhabitants must permanently backfill the holes. This implies that the present (post-Würm) situation is unstable, and the sinking river is re-establishing its former conditions.

Presently the proportion of water that disappears into particular types of ponors is related directly to the absolute amount available and the nature of the actual contribution. Gospodaric \& Habič (o.c., 120) estimated the present total capacity of all of the vertical ponors as being larger than $6 \mathrm{~m}^{3} \mathrm{~s}^{-1}$, whereas the capacity of the cave ponors exceeds $20 \mathrm{~m}^{3} \mathrm{~s}^{-1}$ (o.c., 124). Consequently, it can be concluded that, when the lake is full and all of the ponors are active, an average of $20 \%$ of the total outflow passes directly to the Ljubljanica springs at Vrhnika. Meanwhile, the other $80 \%$ turns towards North-west and, further, to the Eastern Branch of Planinska jama.

Cave ponor openings are ranged along the precipitous, extreme northwestern embayment of Cerkniško polje. After crossing the alluvial cone the river flows over the flat, loamy sediment in the extreme north-western corner of the polje for about $1 \mathrm{~km}$, and disappears into the main (Karlovice ${ }^{3}$ ) ponor caves. Gams (1966) demonstrated that this cave collects water from a wide area, and Šušteršič et al. (2001) offered a structural explanation. This ponor system is here termed 
the Karlovice 4 system (Fig.1). The system continues directly to Zelške jame, which is the main inflow cave in the Rakov Škocjan Valley.

Most visitors' first impressions are that the main channels are epiphreatic, whereas other explored channels, i.e. older, fragmentary, passages up to about $60 \mathrm{~m}$ above the present water table, are mostly phreatic. This becomes especially clear within the entrance part of Zelške jame, where there are several phreatic jumps in close proximity. On the other hand, even in untamed parts of the cave the piles of pebbles are insignificant. This means that water sinking at present may be capable of transporting minor quantities of alluvial load originating in the cone, or even in more remote upper parts of the catchment area, but the total input of mechanical load into the underground is minimal.

However, study of Profile 5 of Pleničar (1953) reveals that the compact cone does not extend as far as the cave ponors. During flood flow the river may bring some pebbles into the cave, but the abrasive effect is probably modest, compared to what could be achieved if the cave opening were in contact with, the compact alluvial cone. In the past the distance between the toe of the cone and the cave was much larger, and the erosional effect of the mechanical load was correspondingly smaller.

Knowledge of land drainage and reclamation during the past few centuries (Gams, o.c., 9-11) raises the additional question of what the "natural conditions" were like. Early authors particularly emphasised the human-induced deepening of the main entrance for a few metres ${ }^{5}$. Reconstructions of the earlier riverbeds (Gospodarič \& Habič, 1979, Fig.18), before the river was artificially controlled, offers more direct information. It appears that none of the recognised former main stream routes flowed into the cave ponors before human intervention.

So, the statements above, that despite being permanently exposed to in-filling vertical ponors are more "attractive" than cave ponors in the longer term and, if undisturbed, they could divert more water than presently, gains added validity. Consequently, addressing the questions of the real former importance of the Karlovice system, and which agent led to its reactivation by the polje outflow (the present Rak), becomes unavoidable.

\section{ABANDONED CAVE SYSTEMS AT THE NORTHERN PART OF CERKNIŠKO POLJE}

The Cerkniščica enters the polje basin through a canyon-like valley, named Kurja dolina by the local people (Fig.1). After leaving the valley the river crosses its own alluvial cone, which covers the northeastern part of the polje. A canyon on its own is a short-lived, transitional feature of a drastically rejuvenated fluvial system. In contrast, most of the upper Cerkniščica catchment area appears to be a relatively well equilibrated fluvio-denudational surface, adapted to a base level of about $610 \mathrm{~m}$ around the village of Begunje (S. Ššteršič, 2002-a, 38), This is about 40m higher than the present main stream elevation at Begunje. Modern incision within the upper Cerkniščica basin, triggered by reversal of the Cerkniščica into Cerkniško polje, and consequently driven by a lowering of the outlet by about $40 \mathrm{~m}$, has influenced only the main tributaries, to form deep, narrow valleys (S. Šušteršič, 2002-b).

Reversal of the river flow was confirmed long ago. Early authors (A. Melik, 1928; J. Rus, 1925; see F. Šušteršič 1996, 256) assumed that the river once flowed on the surface through the present Ravnik lowland towards the present Logaško polje. Since the time of these pioneer 


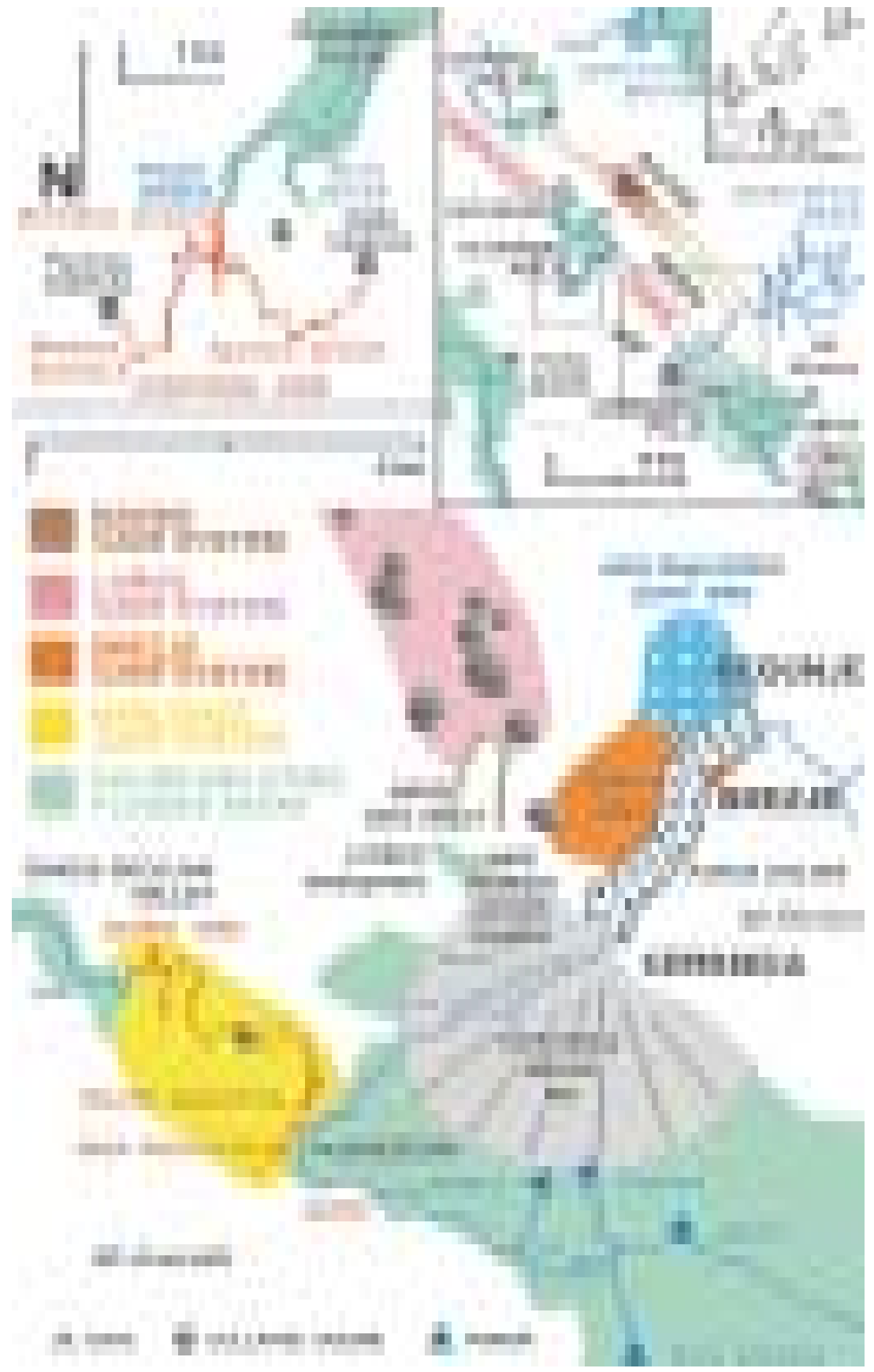

Fig 1.: Locations, mentioned in the text

Sl. 1: Lokacije, omenjene v besedilu 
investigations, the river that existed before the reversal has been termed the Begunjščica, because it did not flow through the present town of Cerknica, which gave the modern river its name.

Based on detailed geomorphological study of the area of reversal, S. Šušteršič (2002-b, 160) demonstrated that the reversal was a relatively rapid, catastrophic, event. Searching for the reasons for the deflection, she noted that the Cerkniščica's characteristic sediments are not preserved at elevations above $610 \mathrm{~m}$ (o.c., 159). On the other hand, her reconstruction of the former slopes of Mt Slivnica, where the Kurja dolina is incised (Fig.2; see also o.c., 158, Fig.2), revealed that the surface stream could not have exited there. The lowest crossing point on the ridge that divides Ravnik from the lowered tract where the karst poljes of south-central Slovenia are located, is still $15 \mathrm{~m}$ higher $^{6}$ than the vertical extent of the Begunjščica sediments.

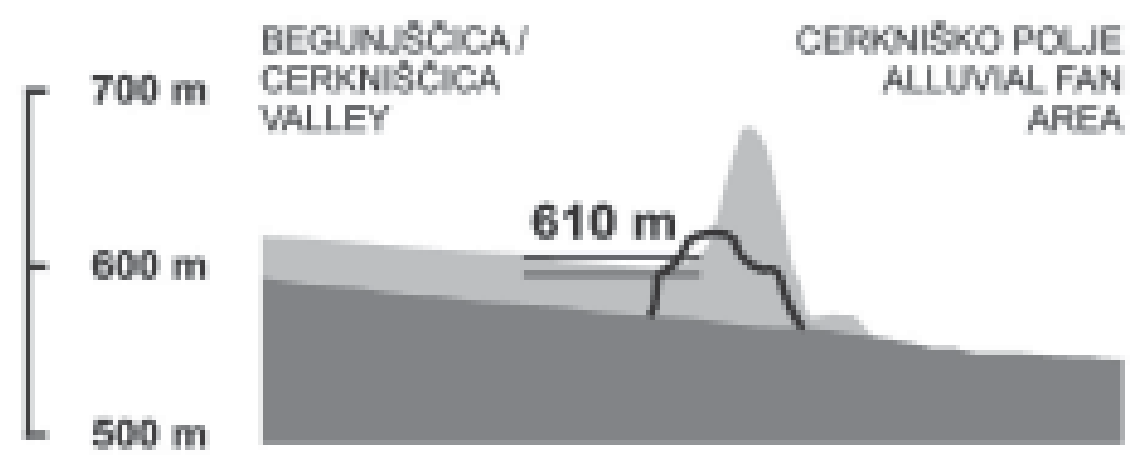

$10 \mathrm{~km}$

$20 \mathrm{~km}$

ᄂ

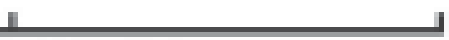

VERTICAL EXMGGERATION $x 20$

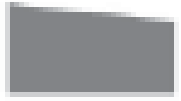

ELEYATIDN DF THE PFESENT

CEAKMSOICA RUEA BED

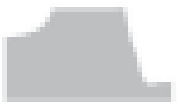

RECONSTRUETOY OF THE EARLY SURFACE SECTIONALONG THE PRESENT RNER COURSE

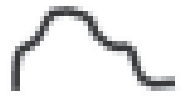

PROFILE ALONG THE LOVEST CROSSING OF THE REGRI RIDGE

Fig. 2: Characteristic elevations between Begunje and Cerknica.

Sl. 2: Značilne višine med Begunjami in Cerknico. 
Such a situation cannot be explained as simple overspill. Pleničar's $(1953,116)$ proposed that deflection of the Begunjščica should be the result of headward erosion of an erosional gully, similar to those in the neighbouring Mt. Slivnica's dolomite slopes. S. Šušteršič (2002-a, 83) analysed their geometry and general setting, and concluded that Pleničar's view is untenable. So, there exists neither material nor indirect evidence that the deflection of the Begunjščica was a surficial event.

On the other hand, within the slopes of Kurja dolina, S. Šušteršič found a number of unroofed caves, filled with laminated quartz sandstone, "basal fill" (see F. Šušteršič, 2002, 74-75, Fig.4; F. Šušteršič, 1998) and massive flowstone. Conglomerates that are characteristic of the Begunjščica infilled unroofed caves in Ravnik (o.c.), are absent. So, S. Šušteršič (2002-a, 81) concluded that there is no objection to the statement that the Begunjščica/Cerkniščica river first entered the polje basin underground, reactivating an old, inherited, cave system, that had been completely filled with sediments much earlier. In the following discussion this idea is pursued as a working hypothesis although positive material proof has not yet been found. This cave system is termed the Brezje system (Fig.1). Consideration of the precise timing of its formation is postponed to the future.

During systematic mapping of unroofed caves in the central part of Ravnik, about $10 \mathrm{~km}$ northwest of the present Cerkniščica, F. Šušteršič (1998) revealed an abandoned, completely infilled $^{7}$ cave system. This system, where the Begunjščica was perhaps just the last to appear, is called the Ravnik system (Fig.1) in the present text. The involvement of the Begunjščica/Cerkniščica is testified by the presence of dolomite conglomerate, identical lithologically to the present Cerkniščica sedimentary load, at the top of the sediment fill. The contemporary stream direction is unambiguous, being confirmed by the presence and relationships of admixed local rock pebbles in the conglomerate (F. Šušteršič, 2002, 74).

Another indicator of location of a cave system that is currently completely inaccessible to cavers, is a cluster of collapse dolines a few kilometres north of Cerknica. Unfortunately, they do not share a common local name that could be used when matching them to the cave system that obviously exists below, which is here termed the Loško system (Fig.1). Although cave sediments have already been identified in this area, more concrete data about the caves in this area have yet to be found.

The dolines are large and relatively mature, in the sense that the slopes are relatively gentle and the perpendicular walls have disappeared (F. Šušteršič, 1973). Slope processes have affected their slopes relatively uniformly, regardless of the depression volumes. No one displays any significant active foci of scree removal. This indicates that the formative (enlargement) processes ceased simultaneously and that the cave system was abandoned abruptly. Even without a profound investigation their existence and location could hardly be explained in any other way than them being related to a once-important but currently virtually abandoned drain, from the extreme northern embayment of Cerkniško polje (Loško embayment) (Fig.1). Minor recent subsidences in the floors of some dolines indicate that, after a time gap, underground flow is resuming.

This system was formerly fed by ponors that are presently choked - termed for convenience the northern ponors (Fig.1) - which might have once accept large quantities of. At this stage water sank in the Loško embayment, a blind valley-like extension of the Cerkniško polje, presently separated from the main polje basin by the Cerkniščica alluvial cone. 


\section{WÜRMIAN DEVELOPMENT IN CERKNIŠKO POLJE}

The first material data about development in the Cerkniško polje basin were published by Pleničar (1953) and later complemented by Gospodarič \& Habič (1979). Šercelj (1974, 237) was much more direct; when summarising his findings on the profile of the "lacustrine-chalk ${ }^{81}$ located at Nova ponikva, he wrote (translated by F.Š., without regard to the original English Summary):

"Our analyses carried out so far have given firm data about the Pleistocene history of the Cerkniško jezero". The Würmian lake is certainly younger than the Cerkniščica's alluvial cone. It appeared approximately at the middle of the Würm (i.e. about 50ka ago), and it stretched eastwards from Goričica. "Lacustrine-chalk" deposited there preserved palaeovegetational and palaeoclimatological records of this time. Compared to the entire area of the basin the lake's size was insignificant, but this was the only true lake proven up to this time. It did not survive until the subsequent (Paudorf) interstadial, which began about 20ka ago. ... So, it may be assumed that the Würmian lake existed between 50ka and 30ka BP, but possibly not for the whole of this 20ka period."

Details that make the information more exact appear somewhat earlier in the text (o.c., 237):

"At the top of the diagram ... the transition to steppe conditions, at any rate to more open land vegetation." ... "One may conclude that a stronger climatic change occurred ... transition to the continental climate." ... "But in general the forest was sparse and heliotrophic species prevailed. Subarctic vegetation, characterised by Selaginella selaginoides ... grew on the neighbouring mountains. After the Brřrup interstadial, approximately in the middle of Würm (i.e. about $50 \mathrm{ka}$ BP and later); such circumstances are also known in other parts of Slovenia."

"... The cone, which included organic matter, choked the vertical ponors ... and formed a dam, behind which the lake appeared. Within this cone, R. Gospodaric ... found a layer of sediment similar to lacustrine chalk. On the basis of its pollen content I placed it within the period at the end of the $\mathrm{Br}$, rup interstadial, i.e. somewhat older than the described profile of the lacustrine chalk (viz. at Nova ponikva, F. S. In the second layer of the same alluvial cone he found pieces of plant remnants ${ }^{10}$. According to the dating at in Groeningen (GrN-6317) they should be $55 \mathrm{ka}$ old. Older sediments than middle Würmian have not yet been discovered."

Šrcelj established that formation of the Cerkniščica alluvial cone took place in Würm II, and the first relatively permanent lake in the polje basin appeared as a direct consequence. Additionally, Pleničar $(1953,115)$ had indirectly excluded the earlier existence of the cone. If it had existed earlier, the river would have deposited its characteristic sediments, including dolomite and bauxite pebbles plus chert gravel. Whereas the main body of the carbonate material would have dissolved by now concentrations of relatively insoluble bauxite and chert would remain. However, they appear for the first time within the actual alluvial cone of the Cerkniščica (Pleničar $\left.{ }^{11}, 1953,115\right)$.

Evidently, inrush of the Begunjščica/Cerkniščica into the polje basin and deflection of the polje main outflow towards Karlovice cave, and further, towards Planinsko polje, went hand in hand (Fig. 3). The question arises, whether the former event sufficed to trigger off the latter one. By combining data from •ibrik \& Pičinin $(1973,5)$ and Gospodarič \& Habič $(1979,103)^{12}$, the following yearly averages of inflow into the polje basin are obtained:

TABLE 1. Average annual discharges of the Cerkniško polje tributaries

\begin{tabular}{lrr} 
Cerkniščica & $1.23 \mathrm{~m}^{3} \mathrm{~s}^{-1}$ & $8.54 \%$ \\
Other tributaries & $13.17 \mathrm{~m}^{3} \mathrm{~s}^{-1}$ & $91.46 \%$ \\
\hline Total & $14.40 \mathrm{~m}^{3} \mathrm{~s}^{-1}$ & $100.00 \%$
\end{tabular}




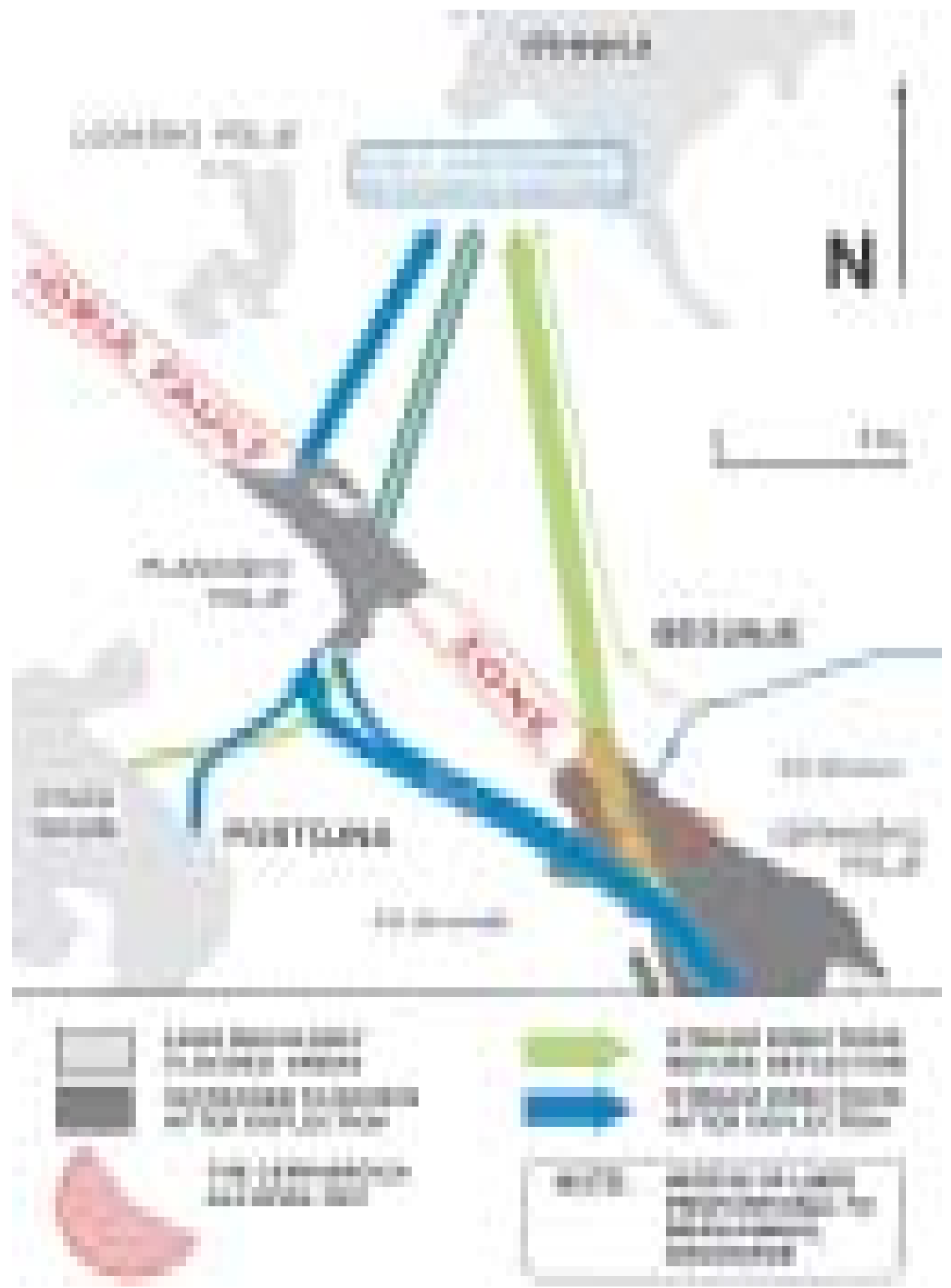

Fig 3.: Change in the Cerkniško polje main outflow direction after the alluvial cone forrmation. Sl. 3: Sprememba v smeri glavnega odtoka Cerkniškega polja po nastanku cerkniškega vršaja. 
An increased input of the Cerkniščica alone $\left(1.23 \mathrm{~m}^{3} \mathrm{~s}^{-1}\right.$; less than $10 \%$ of the total) would have no significant direct influence on water quantities in the polje, which existing ponors could accommodate without any major problem. Its influence upon the development of downstream caves would be equally unimportant.

The Cerkniščica catchment being predominantly non-karstic, the river was able to transport large amounts of mechanical load at times when general circumstances allowed massive gravel production, i.e. during the Würm II and III cold periods. Gravel deposition in the alluvial cone was so massive that it cut off, and eventually completely eliminated, the entire northern ponor area. Consecutively, it deflected perhaps most of the polje outflow into the cave ponors. This indicates that the change in the outflow from the Cerkniško polje, in the direction of Planinsko polje, was due not just to the increased water quantity that entered the polje, but was due predominantly to redirection of the main flow from one ponor group to another.

Augmented flow (perhaps from close to zero to an annual mean of nearly $15 \mathrm{~m}^{3} \mathrm{~s}^{-1}$ ) into Karlovice and beyond, through the Rakov Škocjan valley towards Planinska jama, would increase the input into Planinska jama from the southeast dramatically. Even if the Malni spring at Planinsko polje were capable of transmitting some more water than before, the rest of the underground flow (the present Rak) would push the Pivka (average yearly discharge $4.84 \mathrm{~m}^{3} \mathrm{~s}^{-1}$; • ibrik et al., 1976, 49, Tab.2) away form the Eastern Branch and readily brought about the present hydrological situation in the cave.

Alluvial cone formation undoubtedly commenced at the beginning of the cold period, as is testified by the spruce cone dating (Gospodarič \& Habič, 1979, 43), and by the characteristic appearance of the alluvial gravel itself. This does not negate the view of the timing of the incipient spill over. If the river had found its way into the polje on the surface, it would perhaps be impossible to guess whether this happened during the time of intense gravel production (cold period) or not. However, assuming that the process began as a reactivation of an earlier cave system, it appears more likely to have happened during a warmer period when the river was relatively mechanical load free. Inundation by relatively sediment free water would undoubtedly initiate the washing out of choked channels and, in the course of time, it would increase their transmissivity, opening the way for the gravel transport that was to follow.

One final issue that cannot be ignored is the question of the underlying reason for the overspilling. Accepting the evidence that before Würm II the Begunjščica/Cerkniščica did not flow in its present direction, and the judgement that the deflection was underground, the full question becomes: "What lowered the underground gradient so drastically, so that the Begunjščica was captured, and why didn't it happen earlier?" This cannot be explained by currently known exogenic activity in the polje basin and in adjacent areas.

\section{CONCLUSIONS}

- In the more remote past, the input to Cerkniško polje (and to the caves) was completely karstic.

- At this time the polje was less inundated, or at best reached the same extent as presently.

- Present conditions were established after diversion of the Begunjščica/Cerkniščica into the polje basin. 
- Formation of the relatively permanent lake reflects unstable relationships during the transition from the earlier to the present conditions.

- This activity terminated the functioning of the Loško system and triggered the involvement of the Karlovice system.

- The inundation was more a consequence of the formation of the alluvial cone than related to the increased inflow.

- After breakthrough, large amounts of cryoclastic gravel reached Cerkniško polje at almost the exact location of the main ponors, causing the water to go directly to the Vrhnika springs.

- There is a strong likelihood that the diversion was started by reactivation of an older cave system (Brezje system), choked by sediments, lying between the surficial stream of the Begunjščica and the polje basin.

- Present hydrogeological conditions in Planinska jama are a direct consequence of developments in Cerkniško polje.

- Relatively insignificant geological events may trigger the reactivation of early "frozen" cave systems that were previously filled with sediments.

- Presently regular annual floods at Cerkniško and Planinsko poljes are a result of non-karstic interference with the system.

\section{Acknowledgement}

We thank David Lowe for his efforts in "smoothing" the English translation. 


\section{REFERENCES}

Buser, S., 1965: Geological structure of the Ljubljana moor with special regard to its southern borderland (Summary ${ }^{13}$ ). Geologija, 8, 34-57, Ljubljana.

Ford, D. C., Williams, P.W., 1989: Karst geomorphology and hydrology. Unwin Hyman, 1 601, London.

Gams, I., 1965: On the Quarternary geomorphogenesis of the area among the karst poljes of Postojna, Planina and Cerknica (Summary). Geografski vestnik 37, 61-101, Ljubljana.

Gams, I., 1966: On the hydrology of the territory among the poljes of Postojna, Planina and Cerknica (Summary). Acta carsologica, 4, 5-54, Ljubljana.

Gospodarič, R., 1970: Speleological investigations of the Cerknica cave system (Summary). Acta carsologica, 5, 109-169, Ljubljana.

Gospodarič, R. \& P. Habič, 1976, Underground water tracing. Institute for the Karst Research SAZU, Postojna, 1-309, Postojna.

Gospodarič, R. \& P. Habič, 1979: Karst phenomena of Cerkniško polje (Summary). Acta carsologica, 8, 7-162, Ljubljana.

Jenko, F., 1959: Recherches récentes sur les cours d'eau souterrains du karst Slovčne (Resumé). Acta carsologica, 2, 209-227, Ljubljana.

Pleničar, M., 1953: Contribution to the geology of Cerkniško polje (Summary). Geologija, 1, 111- 119, Ljubljana.

Šercelj, A., 1974: Paleovegetational investigations of the sediments of Cerkniško jezero (Lake of Cerknica) (Summary). Acta carsologica, 6, 233-241, Ljubljana.

Šušteršič, F., 1973: On the problems of collapse dolinas and allied forms of high Notranjsko (Southcentral Slovenia) (Summary). Geografski vestnik, 45, 71-86, Ljubljana.

Šušteršič, F., 1996: Poljes and caves of Notranjska. Acta carsologica, 25, 251-289, Ljubljana.

Šušteršič, F., 1998: Interaction between tha cave system and the lowering karst surface. Case study: Laški Ravnik. Acta carsologica, 27 (2), 115-138, Ljubljana.

Šušteršič, F., 2000: Are collapse dolines formed only by collapse? Acta carsologica, 29, 213-230, Ljubljana.

Šušteršič, F., 2000-a: Speleogenesis in the Ljubljanica river drainage basin, Slovenia. In: A.B. Klimchouk, D.C.Ford, A.N. Palmer, W. Dreybrodt (Eds.): Speleogenesis, Evolution of Karst Aquifers. National speleological society, 397-406, Huntsville.

Šušteršič, F., 2002: Where does underground Ljubljanica flow? Materials and geoenvironment (RMZ), 49, 1, 61-84, Ljubljana.

Šušteršič, F., Čar, J., \& Šebela, S., 2001: Collector channels and deflector faults (Summary). Naše jame, 43, 8-22, Ljubljana.

Šušteršič, F., S.Šušteršič \& U.Stepišnik, 2002-a: Consequences of the late Pleistocene redirection of the Cerkniščica river for the neighbouring karst. In: Gabrovšek, F. (ed): Evolution of karst: from prekarst to cessation. Carsologica, Zalo•ba ZRC, 283-298, Ljubljana.

Šušteršič, F., S.Šušteršič \& U.Stepišnik, 2002-b: Late Quarternary dynamics of Planinska jama (Summary). Naše jame, 44, 25-54, Ljubljana.

Šušteršič, S., 2002-a: Geographical characteristics and development of the Cerkniščica catchment area. (in Slovenian). Unpublished diploma thesis, University of Ljubljana, FF, Dept. of 
geography, 1-96, Ljubljana.

Šušteršič, S., 2002-b: Two phase development of the upper Cerkniščica basin. Acta carsologica, 31 (3), 155-164, Ljubljana.

•alec, P., Vrhovec, T., Mihailovski, M., Zwölf, D., Drole, F., 1997: Cave system Zelške jameKarlovica (in Slovenian). Naše jame, 39, 87-94, Ljubljana.

•ibrik, K., Lewicki, F. \& Pičinin, A., 1976: Hydrologic investigations. In: Gospodarič, R. \& P. Habič, Underground water tracing. Institute for the Karst Research SAZU, Postojna, 4355, Postojna.

\section{Opomba}

Slovenskemu bralcu prirejena inačica tega besedila bo s privoljenjem uredništva objavljena $\mathrm{V}$ reviji Naše jame, 45, 2003.

\section{Notes:}

1 Only data directly connected to the narrower topic are provided. More exhaustive information can be found in works by Gospodarič \& Habič (1979), F. Šušteršič $(1996,2000)$. The newest data on the subject have been presented by S. Šušteršič, 2002, and F. Šušteršič et al., 2002-a, 2002-b.

2 Within the context of the present paper the modern Rak merely presents an intermediate component of the route currently followed by the river from Cerkniško polje to Planinska jama. When speaking about the influence of developments in Cerkniško polje upon Planinska jama in the following text, further references to the role of the Rak and of the Rakov Škocjan valley are omitted, as being self-evident.

3 As this situation resulted from extensive human intervention in the middle of the $18^{\text {th }}$ century (Gospodarič \& Habič, 1979, Fig.18, Appendix), is considered no further.

4 Gospodarič (1970) called it the Cerknica system. This terminology is equivocal, for the same name would be better applied to the cave system termed the Brezje system in this paper.

5 This includes not only the excavation of an artificial river channel in the loamy polje floor, but also enlargement of the ponor cave corridors, widening of narrows by blasting, removal of collapsed boulders, construction of drystone walls and driving of short tunnels (Gospodarič in Habič 1979, 52). In parallel, other (minor) ponor caves, such as Mala Karlovica and Narte, were adapted in the same way.

6 Although, due to the lack of precise data, we avoid exact numbers in this paper, one must not ignore permanent surface lowering due to chemical denudation. In colder periods, however, it is enhanced due to mechanical weathering of the rock, especially of dolomite.

7 It appears that the lower parts of the system are filled with "laminated quartz sandstone", whereas the upper parts contain "basal fill". Later, the latter deposit has partly been washed out and replaced by conglomerate and flowstone, but not at a clearly expressed elevation. Unlike surface stream courses, underground streams in the phreatic zone are not bound strictly to characteristic levels, and the stratigraphical principle of superposition may hold true only coincidentally.

8 Direct translation of a local name for lake sediment composed of precipitated calcium carbonate.

9 In the local dialect the basin of the Cerkniško polje is named "jezero" = "lake". 
10 From Gospodarič \& Habič $(1979,43)$ it follows that a spruce cone was dated.

${ }^{11}$ Due to relatively large admixture of iron, Pleničar (o. c.) termed it "oolite iron ore". Buser $(1965,39)$ refers $53.25 \%$ to $59.93 \%$ of $\mathrm{Al}_{2} \mathrm{O}_{3}$, and $15.74 \%$ to $17.27 \%$ of $\mathrm{Fe}_{2} \mathrm{O}_{3}$

12 The relative difficulty of obtaining absolute data primarily reflects the difficult and unstable field measurements, so that the authors prefer to give only the data of particular observations. Consequently, the final result must be treated with some reservation, though the basic proportions remain relatively constant between different observers.

13 The titles of summaries/abstracts (if they exist) are given just to show the foreign reader the contents of the original texts, which are, however, considered in the whole. 


\begin{tabular}{|c|c|c|c|c|c|c|c|c|c|c|c|c|c|}
\hline & & & & & - & $N$ & $m$ & $\nabla$ & in & $b$ & $r$ & & \\
\hline & 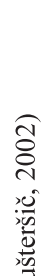 & : & 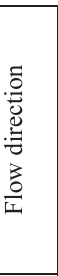 & $\stackrel{y}{i}$ & 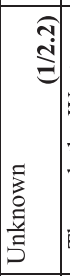 & 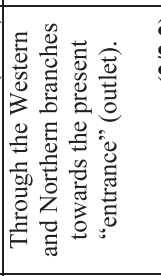 & 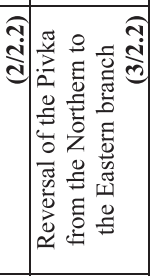 & 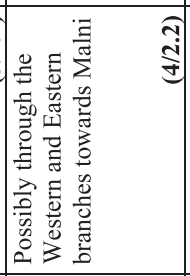 & 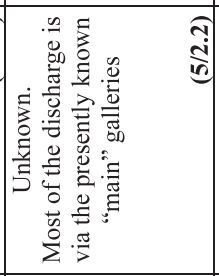 & & 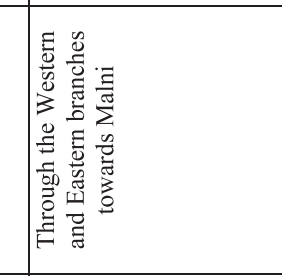 & & 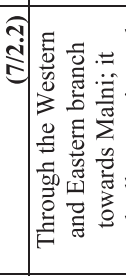 \\
\hline$\frac{\widetilde{\Xi}}{\tilde{\Xi}}$ & 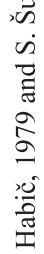 & & 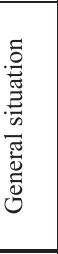 & $\bar{a}$ & 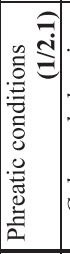 & 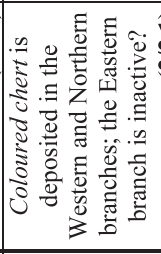 & 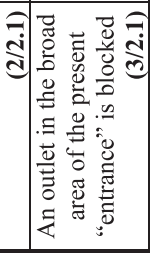 & 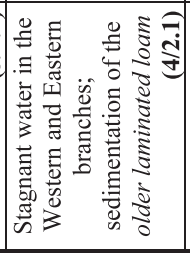 & 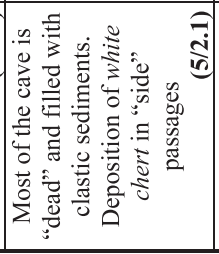 & 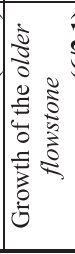 & 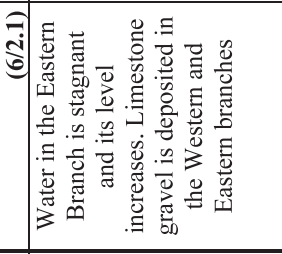 & & 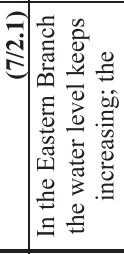 \\
\hline 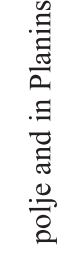 & $\begin{array}{l}0 \\
\infty \\
? 0 \\
0 \\
0 \\
0 \\
0 \\
0 \\
0 \\
0 \\
0\end{array}$ & & 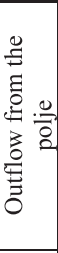 & & & & 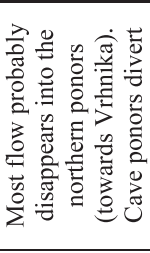 & 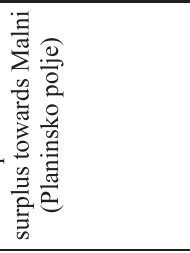 & & & 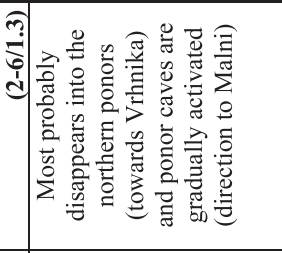 & & 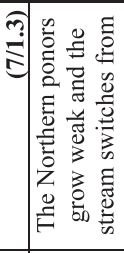 \\
\hline 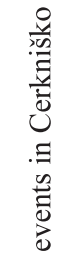 & 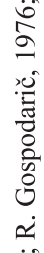 & 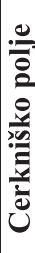 & 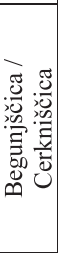 & $\stackrel{-1}{-1}$ & & & 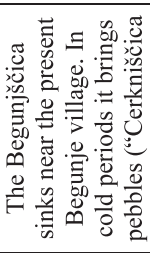 & 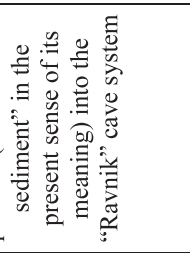 & & & 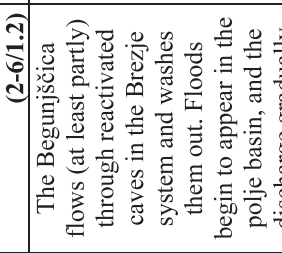 & 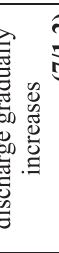 & 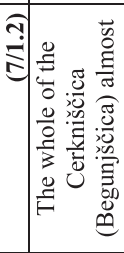 \\
\hline $\begin{array}{l}\frac{4}{0} \\
\frac{0}{0} \\
0 \frac{\pi}{0} \\
\Xi \\
0 \\
0 \\
0 \\
0\end{array}$ & $\begin{array}{l}\tilde{\omega} \\
\dot{\Delta} \\
\ddot{n} \\
\tilde{n}\end{array}$ & & 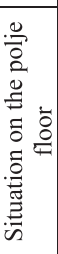 & $=$ & & & 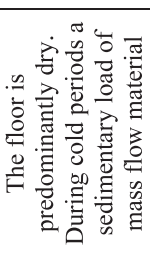 & 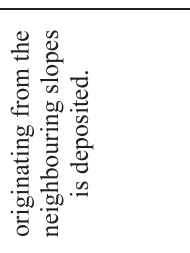 & & & 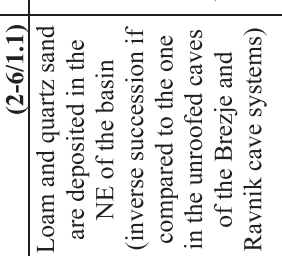 & & 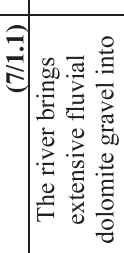 \\
\hline 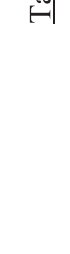 & $\begin{array}{l}\bar{\Delta} \\
\dot{\bar{g}}\end{array}$ & & $\stackrel{\mathscr{\Xi}}{\stackrel{\Xi}{E}}$ & & & & & 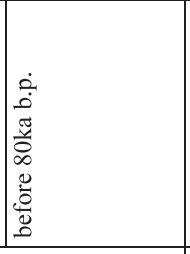 & & 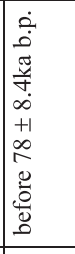 & $\begin{array}{l}\frac{\overrightarrow{0}}{0} \\
\frac{0}{0} \\
\frac{0}{0} \\
0\end{array}$ & & \\
\hline & & & 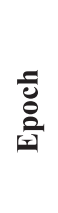 & & & & 长离 & & $\begin{array}{l}\text { ñ } \\
\tilde{2}\end{array}$ & 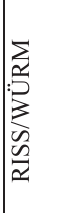 & & 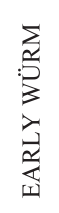 & \\
\hline
\end{tabular}




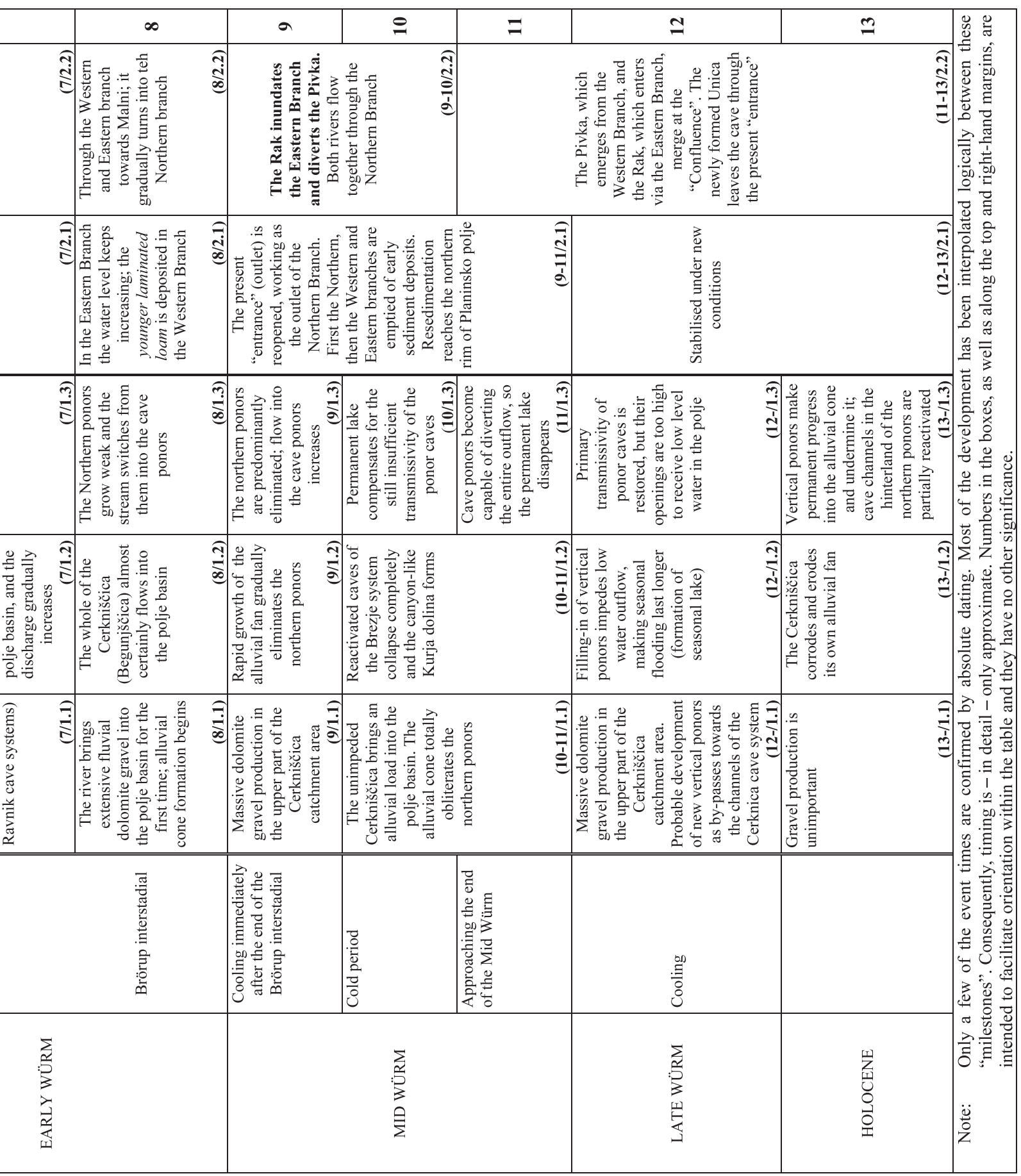

